\title{
Mostar as a "Hopeless Case City " - The Absurd Hopelessness of Objective Circumstances
}

\author{
Milan Vego \\ Faculty of Humanities and Social Sciences, University of Mostar, Mostar, Bosnia and Herzegovina \\ Email address: \\ milan_vego@net.hr

\section{To cite this article:} \\ Milan Vego. Mostar as a "Hopeless Case City" - The Absurd Hopelessness of Objective Circumstances. Advances in Sciences and Humanities. \\ Vol. 7, No. 1, 2021, pp. 8-12. doi: 10.11648/j.ash.20210701.12
}

Received: February 18, 2021; Accepted: March 17, 2021; Published: April 13, 2021

\begin{abstract}
The goal of this paper is to emphasize many objective weak points of the organization of the city of Mostar, which, however, were the reason for marking Mostar as a "hopless case city. "In order to prove his hypothesis, the author bases his research on the Dayton Peace Agreement, as well as on the fact that the two cantons: the Herzegovina-Neretva canton, in which Mostar is situated, and the Middle-Bosnia canton, in which Travnik is situated, were called mixed cantons, and that those two cities should have been organized in the same way. Nevertheless, the international community focused only on Mostar. Additional difficulties were caused by enforced transitional Statute of the High Representative Paddy Ashdown, with which six municipalites (three Bosnian and three Croatian) were abolished, which resulted in aproximatelly 1000 people losing their jobs. Based on these facts and their consequences, the author proves his hypothesis using research methods of deep interview. Additionally, the author researches the time passed in Mostar in mutual conflicts between the Croats, who consider Mostar as their only big city due to the fact that all important institutions are situated there (the only University in Croatian language, the theatre, archives, the hospital, etc.) and the Bosnians, who consider Mostar as the basis for the existence of Bosnia and Herzegovina. During that time of mutual conflicts and fresh war wounds, the Mayor could not be elected for the twelve years. Not only did the author witness the war, but he also witnessed the post-war events in the city of Mostar. The elections for the Mayor were held in 2020, but there were many irregularities seen during the elections. Accordingly, if everything is taken into consideration, there is no justified reason for marking Mostar as a "hopless case city."
\end{abstract}

Keywords: Bosna i Herzegovina, Dayton Peace Agreement, Travnik, Elections, EU

\section{Introduction}

Bosnia and Herzegovina has been a protectorate of the international community. Looking back to 1996, when the first post-war elections were held, which were everything but fair, Bosnia and Herzegovina has had its own institutions: the Presidency, the Parliament, and the Ministry council. Besides that, in the same year, the international comunity appointed the first High Representative Carl Bildt, whose term of office lasted until 1998, when he was replaced by Carlos Westendorp. Carl Bildt's term of office was used for establishing the infrastructure of the OHR - the Office of the High Representative according to the Annex 10 of the General Dayton Peace Agreement for Bosnia and Herzegovina. The main role of the Agreement was: "to help all the conflicted sides in fulfilling their obligations according to the General Dayton Peace Agreement."
Extreemely complicated constitutional organization of Bosnia and Herzegovina according to the Dayton Agreement does not exit anywhere in the world nowadays. "Leaving aside all contradictions related to the sovergnity of the state in the era of globalism, the new international hiarchy and its weak points, the fact is that Bosnia and Herzegovina with its constitutional organization represents a case without precedent in the modern states and constitutions worldwide." [1]

The Dayton Peace Agreement was made without consent by all conflicted sides. It was enforced according to the principle "take it or leave it." While negotiators in Dayton tried to find the best solution acceptable for all conflicted sides, the power and diplomacy were also included. Despite concerns about possible political implications, as well as the possibility of air-raids, the NATO continued with the attacts and used even more modern and dangerous weapons from its arsenal." [2] 
The High Representative was also the highest authority in interpreting the Agreement. At the conference held in Bonn in 1998, the High Representative was given the authority to replace incooperative domestic politicians who violated the Agreement. Westendorp did not use much of his authority in comparison to his successors: Wolfgang Petritsch and Paddy Ashdown, who were succeeded by Cristian Schwarz-Schilling Miroslav Lajčak and the current High Representative Valentin Inzko, whose term of office has been lasting for the last 12 years.

Dayton Peace Agreement divided Bosnia and Herzegovina into two entities: Federation of Bosnia and Herzegovina, which covers $51 \%$ of the entire territory and the Serbian Republic, which covers $49 \%$ of the entire territory.

The Dictrict of Brčko was created in 2000 and has existed ever since, although it was created as a temporary solution. If the fact that in 1996 Mostar was put under rule of the European Union is taken into consideration, then the complete picture of specific state of Bosnia and Herzegovina as something never seen before is made.

The first adminstrator of the European Union in Mostar was the German Hans Koschnick, who was the Mayor of the German city of Bremen after the Wold War II. Koschnick arrived in Mostar in 1994. Remembering his meeting with the representatives of the nations who lived in Mostar, he said: "I expected that the first thing they would tell me would be that they needed medications, hospital equipment, building material. However, they asked me who was to blame for separation among the Christians in 1854?; Who was to blame for the Battle of Kosovo in 1389?; If i knew history; Whose side I supported." [3]

With the Agreement, Mostar was supposed to be a united city with the central city zone. Koschnick was given 100 policemen from Croatia and 100 more from Bosnia and Herzegovina, but who lived outside Mostar. After unsuccessful assault, Koschnick was succeeded by the British Sir Martin Gerod.

These facts clearly indicate separation in Mostar, the city in which bloody distructing battle was fought in which around 2000 people were killed. A great dissatifaction was also caused by the fact that Travnik and the Middle-Bosnia county, in which the Bosnians were the majority nation, was not organized in the same way as Mostar and Herzegovina-Neretva canton, in which the Croats are the majority nation.

In such circumstances of struggle for power, people lived in Mostar. The importance of Mostar for the Croats is best described by the following words: " Among other mistakes made by the Croats, there is the fact that they too easily accepted Sarajevo to be the capital of Bosnia and Herzegovina instead of Mostar or Travnik. That meant centralization of power and everything following it." [4]

Neither Koschnick nor Gerod succeeded to unite Mostar. Dissatifaction of the Croats as the smallest nation living in Bosnia and Herzegovina and an ever-present fear of losing votes affect elections in Mostar as well. On the other hand, the Bosnians do not recognize Mostar as the "capital" of the
Croats, who consider it as their guarantee for existence in Herzegovina.

\section{A transitional Statute of the High Representative Ashdown}

The international community tried to move national parties from the position of power with the elections in Bosnia and Herzegovina, where 14 elections have been held so far; however all those political parties became even more powerful after every election. Immediatly after signing the Dayton Peace Agreement, every side interpreted the Agreement in their own way, therefore the High Representative replaced 3000 domestic politicians who violated the Dayton Peace Agreement.

Mostar was especially interesting since it is the capital of the Herzegovina-Neretva canton. Nevertheless, according to the Agreement, Mostar and Travnik, which is the capital of the Middle-Bosnia county, had to be organized in the same way due to the fact that those two counties have mixed population (Dayton Peace Agreement).

However, the international community, according to its own reasons, focused on Mostar, which, according to some became a "hopless case city", although the entire Bosnia and Herzegovina is "a hopless case."

Until the High Representative Paddy Ashdown arrived in Bosnia and Herzegovina, Mostar had functioned in such a way that it had consisted out of 6 municipalities - three Bosnian and three Croatian. Ashdown imposed the transitional Statute in 2004, with which he abrogated the six municipalities and established a united city, thinking that that would help in creating a faster agreement between the Croats and the Bosnians. "Two Mayors and double companies can not function in Mostar." [5]

Ashdown appointed Werner Wnendt as the senior deputy of the High Representative for Mostar in order to make sure that everything functions well. Wnendt directly involved into the organization of Mostar. When asked what the organization would provide for Mostar, he said: "Uniting the city management is the precondition for any kind of development in Mostar. That is the part of a continuing process." [6]

However, with the abrogation of the six municipalities, 1000 people lost their jobs, which was extremely difficult for the Bosnia and Herzegovina, devastated by the civil war. The Croats sent an appeal to the Constititional court regarding that a Bosnian vote in certain city areas is validated more than a Croatian one. The Constitutional court of Bosnia and Herzegovina decided that the Statute of the city of Mostar, made by Paddy Ashdown, was not constitutional.

That happened in 2010, and not only was the decision of the Constitutional court made into practice, but it was condemned by the Bosnians. That was nothing unusual for Bosnia and Herzegovina, because around 100 decisions made by the Constitutional court have not been made into practice so far.

And while elections were held in Bosnia and Herzegovina, the citizens of Mostar were not able to use their electoral right 
for 12 years, from 2008 until 2020. Finally, in 2020, according to the iniciative of professor Irma Baralija, who sued the state of Bosnia and Herzegovina at the European court for human rights due to disabling of the electoral right, as well as according to the agreement between the leader of the Croatian Democratic Party, Dragan Cović, and the leader of the Democratic Action Party, Bakir Izetbegović, the conditions for holding elections in Mostar were enabled.

Ljubo Bešlić was the Mayor of Mostar for 12 years, during which time he ruled in cooperation with the Bosnian Minister of financy, but without the decision of the City council. For the last year, Bešlić ruled the city from the hospital Rebro in Zagreb, where he was waiting for the operation.

\section{Annex 4 - Constitution of Bosnia and Herzegovina Disables Progress}

The international community organized Bosnia and Herzegovina in such a complex way that the news connstantly appeared indicating that there was no progress, and that especially reffered to Mostar. "Starting from Mostar's Mostar to The Old bridge, from Mostar's blossom to rumors about the biggest Bosnian capital in Herzegovina, from Šantić's Emina to Oručević's Safina from Mostar, from Yugoslavian to Bosnian, from the capital city to municipalities with the majority...from the east to the west, from Koschncik's city to somebody's city on both banks of the river Neretva (that river of Jordan in Herzegovina), there is always something interesting to be found." [7]

The Office of the High Representative (OHR) had its regional offices in Banja Luka, Mostar, Tuzla, as well as the office of the Supervisor for Brčko. The engagement of the OHR in Bosnia and Herzegovina changed through years according to the demands of the Council for peace implementation. State and entity institutions established after the first elections in 1996 did not function immediately. The politics of the OHR in Bosnia and Herzegovina was based on helping and directing domestic officials and institutions to implement laws. The situation in Bosnia and Herzegovina was extemely complicated, in the post-war time and much time was needed for solving certain issues. The international community changed Dayton according to its own needs. " There is no doubt that the international community started using electoral system as 'the most powerful weapon' in order to start parlamentarization of minor multietnic and nonexclusive etnic parties on the expense of the major national parties." [8]

Different civilizations meet in Bosnia and Herzegovina, and each one has its own cultural and political diversities. It could not be described as the Huntingen's clash of civilizations, but different ways of life certainly impact the common living. Namely, in ex-Yugoslavia, nationalism was not emphasized, but people lived together and had got relations. However, there are different points of view as regards the organizations of Bosnia and Herzegovina.

On one hand, the Bosnians want the centralized state; on the other, the Croats want a federal state. The Serbs want the Serbian Republic to become a state, which is impossible due to the fact that they are only one entity living in Bosnia and Herzegovina. The most crucial thing regarding the existence of Bosnia and Herzegovina is whether to establish the federal or the centralized organization. [9] The way of organizing the state should be the way of organizing Mostar, in which two political parties dominate: the Croatian Democratic Party and the Democratic Action Party. Nevertheless, it became obvious at the very beginning that such organization of the state would not function. In December 2003, an iniciative about expanding the Dayton peace Agreement came from the European Parliament. The creator of the Dayton Agreement Richard Holbrook tried to impose the solution to the president Bill Clinton's adminstration, which meant engaging the USA in the Balkans conflict.

\section{Great Expectations from Elections in Mostar}

The elections held in 2020, after surprising results in Banja Luka and Sarajevo, where the oposition parties won, were a good oportunity that the same thing would happen in Mostar. However, the major national partie, the Croatian Democratic Party and the Democratic Action Party, prevented that. Neverthesless, in the Mostar City council, counting 35 members according to the official results of the Central electoral commision of Bosnia and Herzegovina, with which the leading Croatin political party, the Croatian Democratic Party, in Bosnia and Herzegovina is dissatisfied, and sued it to Procecutions authorities of Bosnia and Herzegovina, the following members were elected: 13 councelors from the Croatian Democratic Party, followed by the Bosnian Coalition counting 12 councelors; 6 councelors will make a bridge consisting of Social-Democratic Party and Our Party; Croatian Republican Party will have 3 councelors; and 1 councelor from the Serbian list "Stay here."

The Mayor is elected directly from the rank of councelors. According to the Statute, if no candidate is elected in the first two cycles by two-third majority, in the third cycle, the Mayor will be elected by the ordinary majority. The Croatian Democratic Party candidate for the mayor is Mario Kordić, M. D., whereas the candidate from the the Democratic Action Party is Zlatko Guzina, M. D.

As regards to the elections held in Mostar, 55\% of voters voted, which is according to some a low percentage ragarding the fact that the elections had not been held for 12 years. Two months have passed since the elections in Mostar were held. There were many opstructions, arguments, the City Council's meeting was postponed several times until, finally, the Mayor was elected and that is Mario Kordić, M. D., the candidate from the Croatian Democratic Party. The coalition for Moatar and the bridge from Bosnia and Herzegovina were unable to make an agreement which way they would defeat the leading Croatian Democratic Party. Kordić won 17 votes, Guzin won 16 votes, wheras two votes were not valid. However, even the 
High Representative, Valentin Inzko, had to involve warning that the Statute of the city of Mostar was violated and that there should be secret voting held, which was unacceptable for the councelors.

The agreement between the sides in Mostar is something of the greatest importance, and it is extemely difficult to be made due to everything that had happened before. Such Bosnia and Herzegovina can not function as an independent state, and the autor of this paper thinks that an improvement is only possible if the USA involves.

The USA after Trump will be different because it will reenter the World Health Organization and the Paris Agreement about climate changes. The new American adminsitration led by the president Biden is interested in finalizing the work on the Balkans since the Dayton peace Agreement stopped the war and it is high time the state were organized according to the standard of West-European states. Accordingly, Zbigniew Brzezinski says „The USA perceives itself as the world's number one state as regards to democracy and it indeed, even subconsciously exports democratic values via globalization - however, that simultaneously causes certain expectations from the USA, which can hardly meet hiarchy demands from a hegemone power." [10]

In order to provide that the USA reinvolves into unsolved issues on the Balkans, some relations between the USA and the European Union need to be examined, i.e. trans-Atlantic relations. Such relations are much closer nowadays than ever before. That especially refers to North-Atlantic Aliance, which provided a certain peace on the Balkans. Accordingly, Kinsinger says:" Despite that, in the world when historic relations are becoming weaker, personal relations among the leaders of the Atlantic states remained suprizingly good during Clinton's adminstration." [11]

The European Union wants that all state from the western Balkans join it. "Different political powers, which in the European Parliament looked for single politics towards Mediterranean started from different goals and intersts, but the need for the presence on the Mediterranean was common to all of them." [12]

The elections held in Mostar have not brought expected changes, but the citizen have chosen what they wanted. Some will remain disapointed because they did not make a good score, however, the others will be satisfied.

"We followed our principles and with our abstinence we tried to preserve the idea of the civic state on the example of the city of Mostar. The most important thing is that the Mayor has been elected, as well as the City council, and that the problems are going to be resololved."[13]

Mostar continues living its everyday life being divided by the invsible border into the left and the the right.

University profesor Mile Lasić expresses his opinion about the elections held in Mostar: "Elections held in Mostar in December 2020 have shown that also in this part of the world we are not able to face with the managing differences according to the highest democratic rules in multinational states. What is more, in the Bosnian part of Bosnia and Herzegovina, Bosnia and Herzegovina is not recognized as a multinational state. It is especially absurd, however, that those who are "tongue-tied" to themselves have wanted Bosnia and Herzegovina patriots even in the conditions in which they are national minority to ignore the majority, in this case the Croatian majority. However, it was especially fatal error to establish Bosnia and Herzegovina partiotic front in the capital of Herzegovina; would it not be similarly absurd if in Sarajevo Herzegovina-Bosnia front were established? Unfortunatelly, it is not convenient for many that Mostar stops being "a hopeless case cityn". [14]

The situation is much different in comparison to the situation immediatelly after the war. People cross from one bank of the river Neretvta to the other, the young hang out. The Croats are the minority nation in Bosnia and Herzegovina and accordingly, they are often being majorized by the Bosnians. " The examples of relegating the Croats from the basic political rights, often based on the constitutional category of the consitutivity of the nations as regards to the other two constitutive nations, unfortuantelly, are numerous. Non-legitimate election of the Croatian member of the Presidency of Bosnia and Herzegovina by the Bosnian votes in three terms of office, being supported by a drastic maluse of the orders of the existing Constitution and the Elective law thorough political cessions are contrary to the Constitutions itself and the provisions of the equality of the nations. "[15]

The election of the Croatian member of the Presidency of Bosnia and Herzegovina by the Bosnian votes caused a huge dissatifactions, which has made a huge impact on Mostar, which is consdered to be a capital city by the Croats. In the Constituation of Bosnia and Herzegovina, Annex 4 of the Dyton Peace Agreement, the folowing is written: "The election of the members of the Presidency of Bonia and Herzegovina includes election of one Bosnian and one Croat from the territory of Federation of Bosnia and Herzegovina, as well as one Serbian from the territory of the Serbian Republic. Thanks to the ingeneering in the Election law, Želko Komsic was elected in three terms of office, which was not the will of the Croatian people. Nevertheless, The Venice Commission suggested annulment of the House of Representatives, in which the vital national interests are being protected." [16]

However, the fact how much this truce is fragile confirms the fact that when the city rivels Zrinjski and Velež are playing. The fans arrange conflict on the central city square via the Internet and in such a way the aeyrs of buildn peace are getting lost. When asked what newly elected Mostar Mayor, Mario Kordić, from the Croatian Democratic Party, think about Mostar as a "hopless case city" and what his visions about the future Mostar are, he says:" Unfortunatelly, Mostar, as well as his citizens have long been a hostage of unsolved conflicts in Bosnia and Herzegovina, more precisely in the Federation of Bosnia and Herzegovina, and for many years the story about Mostar as a "hopless case city" has been emphasized. That story mostly came from Sarajevo and it was also used to redirect the emphasis from other more important topics. Some also had both political and personal benefits from that, and I think the day has come to stop that and leave Mostar to 
organize its own relations by itself. Finally, after twelve years we had democratic elections and I think that the time has come that we ourselves organize Mostar as a normal European city. Mostar has a great potential in every sense and it the people who are the largest potential. We have to create the atmosphere and the conditions so that the young can stay and not leave to some other states, but to live here, educate and make their families here. I, as a Mayor, also have a large responsibility and the job to create such an atmosphere and to communicate positive ideas and the approach..." [17]

The thing that I can promise is that I will make an effort with all my knowledge and energy on ne benefit of the promotion and development of Mostar as such a city which will gather, not divide, the city turned to future, and not being the prisoner of the past. I will make and effort so that Mostar will be organized as amultinational city, in which all the nations and its citizens will be satisfied and have a chance for a good life."

It is supposed that even if Travnik and Middle-Bosnian county had been organized as Mostar, the situation would have been similar, or maybe the same.

Accordingly, the question asked here is if Mostar then has deserved to be called a "hopeless case city." The answer is "No" if all the facts are taken into consideration.

\section{Conclusion}

If everything said is taken into consideration, it can be concluded that not only in Mostar is the consensus a word of magic, but in the entire Bosnia and Herzegovina. It is really interesting that it has been imposible to make a concensus for the twenty five years despite the coercion of the international community in the form of the OHR and the seven High representatives. Starting from the Dayton Peace Agreement until tody, national parties, presenting themselves as legitimate representatives of the three constitutive nations (the Bosnians, the Srbs and the Croats) have used their territories and followers and do not retreat for a milimetar. Mostar unjustifiably got its name as a "hopeless case city", because it is supposed that it would have been Travnik had interantional community tried to organize it. Likewise, Washington Agreement had an arangeement on the Confederal relation of the Federation of Bosnia and Herzegovina and the Republic of Croatia, which ensured the parity in all future institutions for the Croats. With the Dayton Peace Agreement, the Washington Agreement has totally been forgotten. Bosnia and Herzegovina has a strategic external approach to NATO and the entrance into the EU, but it is not going to happen soon according to the present internal organization and different politics, because the Bosnians want a centralized state, the Croats want a decentralized state, and the Serbs, preserveing the entity the Serbian Republic, do not think much about the Bosnia and Herzegovina.

The key question is how to coordinate civic and ethnic, because it must not be forgotten that the nation issue has not been resolved in Bosnia and Herzegovina. It is thought that only by engaging the USA, as a creator of the Dayton Peace Agreement, into the solving the issue of Bosnia and Herzegovina, tha final solution on the benefit of all nations living in Bosnia and Herzegovina can be found.

\section{References}

[1] Bildt C.: "Misija i mir", Interliber, Zagreb, 1998.

[2] Brzezinski, Z.:"Velika šahovska ploča", Interland, Varaždin, 1999.

[3] Cholet, D.:"Tajna povijest Daytona," Golden marketing-Tehnička knjiga, Zagreb, 2003.

[4] "Daytonski mirovni sporazum," Dayjton-Pariz, studeni-porosinac, 1995.

[5] "Hrvati Bosne i Hercegovine-nositelji europskih vrijednosti," znanstveno-stručni skup s međunarodnim sudjelovanjem, Zbornik radova-drugo dopunjeno izdanje, Neum, 2017.

[6] Huntigton, S. P.: "'The Clash of Civilizacions and the Remaking of Word Order", New York 1996.

[7] Holbrooke, R.: "Završiti rat, Šahinpašić", Sarajevo, 1998.

[8] Lijphart, A.: "Parlamentarna ili predsjednička vlast," F. P. Z., Zagreb, 1998.

[9] Kasapović, M.:" Bosna i Hercegovina podijeljeno društvo i nestabilna država", Politička kultura, Zagreb, 2005.

[10] Kissinger, H.: "Treba li Amerika vanjsku politiku, Prema diplomaciji za 21 stoljeće, "Golden Marketing, Zagreb, 2003.

[11] Markotić, F. A.: "BiH NE BIH," Crkva na kamenu, Mostar, 2005.

[12] Miljko, Z.: Ustavno uređenje Bosne i Hercegovine, Hrvatska sveučilišna naklada, Zagreb, 2006.

[13] Petritsch, W.:"Bosna i Hercegovina od Dayona do Europe", Svijetlost, Sarajevo, 2002.

[14] Vukadinović, R., i Čehulić, L.: "Politika europskih integracija," Biblioteka europske integracije, Topical, Zagreb, 2005.

[15] Žepić, B.:" Enigma Bosna i Hercegovine", Matica hrvatska, Mostar, 2003.

[16] Vego, M.: "Međunarodna zajednica i Bosna i Hercegovina, Kakva je bila uloga međunarodne zajednice a kakva domaćih elita 1990.-2010". Ziral, Mostar, 2012.

[17] Lasić, M.:" Izjava Milanu Vegi," ožujaK, 2021. 